\title{
Abuse of Power, Gender Violence and the Tragic Convention: the Dénouement of No hay cosa como callar by Calderón ${ }^{\top}$ \\ Abuso de poder, violencia de género y convención trágica: el desenlace de No hay cosa como callar de Calderón
}

\section{Ignacio Arellano}

Universidad de Navarra, GRISO

ESPAÑA

iarellano@unav.es

ORCID: http://orcid.org/0000-0002-3386-3668

[Hipogrifo, (issn: 2328-1308), Volumen extraordinario, 1, 2018, pp. 9-21]

Recibido: 23-05-2017 / Aceptado: 23-06-2017

DOl: http://dx.doi.org/10.13035/H.2018.extra01.03

Resumen. This article analyzes the dénouement of Calderon's No hay cosa como callar, with the aim of showing the tragic quality of the work, which destroys the possibility of the central character being happy, as she has been raped by a cynical and abusive gentleman.

Palabras clave. Calderón; Tragedy; Violence; Code of Honor; Secret.

Abstract. Este artículo analiza el desenlace de No hay cosa como callar de Calderón, para demostrar la calidad trágica de la obra, que anula las posibilidades de felicidad de la protagonista, violada por un caballero cínico y abusador.

Keywords. Calderón; tragedia; violencia; código del honor; secreto.

1. This work is part of project FFI2014-52007-P, Authority and Power in the Theatre of the Golden Age. Strategies, genres, images in the first globalization, Ministry of Economy and Competitiveness, Government of Spain. Directorate General of Scientific and Technical Research. National Programme for Fostering Excellence in Scientific and Technical Research. This project has benefited from the collaboration of the Santander Bank in GRISO research. 


\section{«NO HAY COSA COMO CALLAR», TRAGEDY OR COMEDY? A SURVEY OF THE QUESTION}

It would be advisable, before again ${ }^{2}$ addressing the category of this admirable play by Calderon, to give a brief synopsis of the action.

Don Juan de Mendoza, a cynical and carefree philanderer, whose «dama fija» is Marcela - to whom he is unfaithful and forgets when he feels like it ${ }^{3}-$, falls for Leonor who has an honorable relationship with Don Luis. After a fire forces her to leave her home, Leonor is given shelter by her neighbor Don Pedro, the father of Don Juan. The latter returns to his bedroom to pick up some papers that he needs for his journey to Fuenterrabía (where he will take part in the freeing of the city, which is under siege by the French), and there surprises and rapes Leonor and then escapes immediately, leaving a scallop-shaped locket with a portrait of Marcela in the hands of his victim. For two months Leonor suffers her misfortune in silence. But one day Marcela's coach overturns and the lady is given help in the home of Leonor, who recognizes her as the woman in the portrait. Leonor finds out where Marcela lives and goes there, wrapped in a cloak, to investigate the identity of her attacker, only to be forced to drop the locket and run away without achieving her objective due to the unexpected presence of Don Diego (Leonor's brother who has been in love with Marcela since the day of the coach accident). Don Juan and Don Luis return to Fuenterrabía. On their way, Don Juan tells his friend about the rape adventure, but is unaware of the identity of the woman. Leonor breaks off her relationship with Don Luis, who is in the dark about the cause of this breakup and the sadness of his lady. In order to make Don Juan jealous, Marcela presents the locket to Don Diego, whereby the object returns to the home of Leonor, who again seizes the portrait which she finds lying on a chair. Finally, in a jealous quarrel which breaks out in Marcela's house, Don Juan wounds a man and by chance takes refuge in Leonor's house: this is the moment when they recognize each oth$\mathrm{er}^{4}$. Leonor suggests that the philanderer should make amends for her dishonor by marrying her or, at least, by keeping the secret while she shuts herself away in a convent. Don Juan rejects marriage, but Don Diego and Don Luis appear and surprise Don Juan arguing with Leonor in enigmatic terms referring to honor. Then old Don Pedro, Leonor's guardian arrives, and, in view of the complicated situation, Don Juan agrees to the marriage, with no further explanations. No explanations are required and, thus, the play finishes.

\footnotetext{
2. As will be seen, the critical discussion on the genre status of this play is complex and has already received quite a few interpretations on which I will comment shortly.

3. «Marcela / es dama de cada día; / ni entra ni sale en la cuenta. / Todo ocioso cortesano / dice un adagio que tenga / una dama de respeto / que sin estorbar divierta...» (p. 1002). This characteristic could be typical of a philanderer if the framework was a comedy. I quote from the edition by Valbuena, in Obras completas. I. Comedias.

4. Please note that the locket comes and goes from hand to hand but does not affect the action nor has it any role in the anagnorisis, which responds to other cases of chance. I analyze the role of this object in Arellano, 2013.
} 
The apparent structure of a cloak-and-dagger comedy (the rank of the characters, the coetaneous transitoriness of the spectator, onomastics, hit-and-miss affairs... $)^{5}$, together with the brutal case of the rape and humiliation of Leonor have posed much-repeated complications for scholars, who wonder how to classify this play ${ }^{6}$. Significantly, Rodríguez Cuadros ${ }^{7}$ states: «La incomodidad viene, probablemente, de la falta de nitidez de los componentes trágicos y cómicos de la pieza».

In Arellano ${ }^{9}$ I have defended the tragic dimensions of this work through a series of arguments which I will not repeat; in the most recent work I have found on the play, Marc Vitse ${ }^{10}$, with his usual mastery and acuity, contradicts my conclusions but does not justify the supposed impertinence of my comments, and argues among less essential reasons - that both Don Juan and Leonor are «redeemable» characters and that their story allows for a normalizing end and conservation of the honor of both parties. Thus the work would deactivate or neutralize the tragic elements resulting in a peculiar cloak-and-dagger comedy, certainly more comical than tragic.

The bases which would allow for this comedy -or at least 'happy' - consideration of the work would be Don Juan's condition as a «redeemable» philanderer, as he is complies faithfully with the code of chivalry, and Leonor's admirable heroism, which lead to an ending that is triumphant and, therefore, happy, a feature of comedy.

The scholar from Tolosa finds that Don Juan observes the code of chivalry in his efforts during the patriotic war of Fuenterrabía and in his amorous and honorable conduct. But where is such conduct to be found? In the observance (Vitse claims) by Don Juan of the code of true love, seen in his sudden infatuation, which would be an example of "concordancia con el código de amor verdadero»" ${ }^{1}$, as he becomes fascinated by the «divine» beauty of Leonor. And Don Juan would show his observance of the code of honor -among other ways - by refusing to marry a woman who can only be considered «a strumpet», as he found her in the room where he himself raped her, because an honorable gentleman may only marry a lady of irreproachable purity, a quality which he is certain Leonor does not have as he knows she has been raped (by him, obviously). Because Don Juan «no tiene hasta ahora la

5. The feature which differs most from what is usual is the duration of the action, over two months, compared to the characteristic time constriction of the cloak-and-dagger genre.

6. I shall only quote from the studies that are most relevant for my purposes. A more systematic discussion of the genre of this work and its tragic interpretation, with the pertinent bibliography, can be found in Arellano, 2013

7. Rodríguez Cuadros, 1988, p. 143.

8. To my mind, the lack of clarity corresponds more to some scholars' perception than to the design of the piece. Escudero (2013) deals with some of these doubts but still does not precisely clarify some fundamental points such as the role of the locket (to which he grants the importance which does not correspond to the textual reality), etc. I believe, as I have said, that the work is quite clear. Just notice the fundamental (tragic) elements and the secondary comic ones, (which do not affect the global character). 9. Arellano, 2013.

10. Vitse, 2015. I respond to Vitse in Arellano, 2018.

11. Vitse, 2015, p. 30. 
información suficiente para dejar de pensar que la mujer que halló casualmente en su aposento no podía ser otra cosa que una mujercilla»12: this philanderer

nunca aceptará casarse con una mujer sin honor. Con ello no solamente previene cualquier eventual reclamación de parte de la para él mujercilla a la que acaba de gozar [...] también reafirma la ley de los celos de honor que quiere que para todo caballero de la sociedad dramática calderoniana es impensable e inaceptable el casamiento con una dama objeto de la más leve sospecha contra su honor ${ }^{13}$.

Strangely, and unusually for Vitse -always a meticulous and intelligent analyst of admirable discernment- in this description he ignores the very text of the play. As I have indicated elsewhere ${ }^{14}$, in writing these lines he overlooks the fact that it is Don Juan himself who has ruined the violated lady. And the philanderer knows perfectly well that the lady is not a fallen woman. In the key scene of the rape, Leonor -in a speech whose linguistic quality in itself proves her social standing- asks him if he is a gentleman and warns him that she is better than he appears to think. To both comments Don Juan responds in contradiction of the obligations of a gentleman, which he explicitly ignores:

\begin{tabular}{lc} 
LEONOR & ¿Vos sois noble? \\
DON JUAN & No lo sé. \\
LEONOR & Mirad que soy... \\
DON JUAN & \multicolumn{1}{c}{ Nada advierto. } \\
LEONOR & ... más que pensáis. \\
DON JUAN & Poco importa. (p. 1012)
\end{tabular}

But moreover Don Juan recognizes the woman in the bedchamber as the lady who had earlier attracted his attention (as pointed out by the servant Barzoque: «pues es la mujer que está / sobre esa silla durmiendo / la misma que adoras», p. 1011). And he had met this lady who he had seen and suddenly loved at the mass of St. George, and had described her as a goddess, a beauty above all others (pp. 1000-1001), calling her a lady (p. 1003), and believing «que una mujer como aquella / a pie no fuera muy lejos» (p. 1002), that is to say, he considers her a lady worthy of traveling by chair or coach, which is confirmed when we, and Barzoque and Don Juan, see Leonor accompanied by a squire and a woman servant sending for her sedan chair ... All these details which Don Juan knows prove that the lady is far from being «a strumpet» can be raped with impunity.

In short, Don Juan is completely aware that he is raping a lady whose identity is unknown to him but who is of obvious good standing, thereby dishonoring her and destroying her life. 
On this occasion, I am not interested in re-examining Don Juan's conduct regarding the code of chivalry, nor the ineffectiveness of the supposed strategies that many scholars see in Leonor's conduct, with the intention of amending her honor. Up to now I have not found in any reviewer the bases for these admirable strategies $^{15}$ to which Vitse again grants essential value in his portrait of a triumphant Leonor who heroically manages to amend her honor by means of a marriage which, although it does not bring her «loving» happiness, does mean an «honorable» happiness, a kind of happiness which does not seem very acceptable ${ }^{16}$ and has all the characteristics of a desperate solution.

This supposed triumph becomes a reality, for many critics, in the dénouement. We must, then, pay a little more attention to the dénouement of No hay cosa como callar.

\section{THE DÉNOUEMENT. SECRETS OF HONOR AND PROOF OF INSULT}

Rodríguez Cuadros ${ }^{17}$, on the speaking of «the strange comedy» No hay cosa como callar, considers that its «mapa estético de vocación trágica solo se resuelve a última hora del lado restaurador y tópico de la comedia de capa y espada». A hackneyed cloak-and-dagger ending that is, therefore, remedial.

The happiness of such a dénouement has been defended above all -with a certain amount of naïveté- by Fausta Antonucci, as Leonor triumphs and confirms the ludic character of the work:

non si arrende affatto. La sua è una scelta obbligata, è vero, ma portata avanti con lucidità estrema. Non è una resa, è una battaglia condotta con strategia perfetta e finalmente vinta. Solo in un genere ludico comme la commedia poteva trovare cittadinanza questa vittoria della donna ${ }^{18}$,

And elsewhere:

L'obiettivo di Leonor, a partire dalla violenza subita, è il matrimonio con il suo offensore; obiettivo regolarmente raggiunto alla fine dell'opera [...] quella [lettura] di tutti coloro per i quali il finale di No hay cosa como callar è sostianzialmente tra-

15. Enough to point out that the impulses of the action are made up of chance events, and that the apparent structure of a comedy of intrigue is absent in No hay cosa como callar, as I have studied in Arellano, 2013, in such a way that nothing that Leonor does (merely keeping silent and undertaking some actions that do not work) demands an ingenious response capable of modifying course of the events. Only coincidences allow the action to develop.

16. «La violentada figura de Leonor cerrará definitivamente la puerta de la felicidad amorosa», persiguiendo entonces el honor como «felicidad honrosa» (Vitse, 2015, p. 35). This concept, without going any further, permits the dénouement of El médico de su honra to be considered a happy ending, both amorous (because of the marriage of Don Gutierre ) and honorable (as Don Gutierre safeguards his honor).

17. Rodríguez Cuadros, 1988

18. Antonucci, 2003, pp. 166, 169. But the reference to a «forced choice» («scelta obbligata») is in itself contradictory. If it is forced it is not a choice. 
gico, parte da presupposti che sono in gran parte estranei all'universo ideologicosentimentale della commedia calderoniana [en el cual] é proprio dare la priorità all'onore [...] È ciò che fa la Leonor di No hay cosa como callar, non potendo più conciliare amore ed onore, persegue esclusivamente l'onore [...] È fuor di luogo quindi parlare di matrimonio «indeseado», «contra su voluntad»: anzi, è un matrimonio desiderato, e cercato con tutta volontà della protagonista [...] nelle commedie viene alla luce, trionfante, I'altro aspetto, antiteico, del loro essere donne: la forza ${ }^{19}$.

This passage confuses some extremes: in the impossible conciliation of honor and love, the fact that honor is chosen does not mean that such a ('forced') choice is a triumph and happiness. The choice may well imply tragic suffering. In many works the priority of honor is precisely what brings about the tragic tension. And how can it be inappropriate to describe Leonor's marriage as undesirable? In situations of free choice - which does not exist once she has been raped- Leonor would never choose the marriage she finally achieves. She wants it with every fiber of her being, but her will is no longer free from the moment when she received an insult which must be put right. And analysis of the dénouement which ignores the pressure of the violence which she has suffered means trivializing the concept of 'free will' with which Leonor is credited.

But if for the moment we leave the matter of love aside and focus on honor and silence, in the commentaries on No hay cosa como callar, we find opinions such as those of Déodat-Kessedjian, who goes so far as to paradoxically consider the silence and secret as a victory for the lady, an expression of her self-control and strength, a sort of virtue and heroic resistance:

se domina bastante como para silenciar la causa de su infortunio [...] gracias a procedimientos distintos logrará [...] no romper el silencio...

LEONOR [.... gracias a un dominio de sí misma excepcional, ha conseguido guardar el silencio sobre su deshonra hasta el final y se decide a romperlo cuando esta deshonra pasa a ser pública... ${ }^{20}$

Vitse $^{21}$ supports his appreciation of Leonor's silence -as a heroic feat for the lady -, with some contradictions, as, on the one hand, he states that silence is the chosen strategy (un-imposed ${ }^{22}$ ), and later speaks of the -momentary- «liberación» from her word, which, in the dénouement, is again buried in silence («puede por fin liberar su palabra y sin revelar nada de su deshonra [...] obtiene un casamiento reparador» $\left.{ }^{23}\right)$.

\section{Antonucci, 2003, pp. 166-169.}

20. Déodat-Kessedjian, 1999, pp. 246 y 256. Keep in mind that Déodat-Kessedjian considers that Leonor's dishonor is public. Vitse, on the other hand, believes that she manages not to reveal her dishonor to anyone.

21. Vitse, 2015

22. Of course it is imposed on her; it is imposed by the code of honor which prohibits publicizing one's dishonor.

23. Vitse, 2015, p. 41, my emphasis. 
Vitse describes Leonor as a skilled investigator who manages to find her rapist and restore her honor through marriage, once more identified as a happy ending, while simultaneously managing to keep her dishonor secret.

However, in another passage (p. 39) we learn that Leonor is denied any means of action «y condenada al silencio». Condemned to silence is, in fact, a much more exact description, to my mind, than that which he suggests, a few lines further on, when he says that «se mostrará capaz de no revelarle nada a don Luis que concierna a la devastación de su honor ${ }^{24}$, as if that silence were a heroic feat and as if that silence could keep the secret from Don Luis. But this is neither a strategy nor does it express any valor: how could she admit her dishonor to her betrothed? It is not a silence «escogido y asumido por la víctima» ${ }^{25}$ but rather is forced by the very fact of being a victim. The fact that she does not demand scandalous public reparation is no surprise ${ }^{26}$ («con gran sorpresa de su auditor -y podemos suponer de los oyentes del teatro- no va a tratar de vengarse, es decir, de pedir reparación haciendo público el escándalo de su violación»), because this can cause no surprise to the audience who know the conventions, that is to say, Vitse cannot be surprised by this; as several characters throughout the play repeat, affairs of honor demand secrecy and Leonor cannot make her own dishonor public.

Scott Soufas ${ }^{27}$, makes a better point, although some of her statements are qualified, when she emphasizes the function of silence as a safeguard of Leonor's honor and life, but not as a useful tool to restore this honor.

In my opinion, it is quite clear that Leonor can but keep silent, because if she spoke she would merely be making an exhibition of her dishonor. Her silence is not a heroic feat, but more a resigned and inevitable attitude for the violated lady.

But independently of the subjective considerations (in as far as they refer to Leonor) of the purposes of her silence, we should return for a moment to the dénouement to confirm or refute whether Leonor manages, as Vitse affirms -an opinion that is shared by other scholars - to reveal nothing about her dishonor, that is, we should clarify if her silence really manages to hide the abuse.

In the scene Leonor demands restitution from Don Juan, and he refuses to be wed, but offers to keep the secret. In the conversation this philanderer shows her no mercy and insults her -undoubtedly an excuse- by stating that he cannot marry a woman whose reasons for being in someone else's house are unclear to him and may well be dishonorable. Leonor responds indignantly to this insult and defends the purity of her honor:

24. She does not reveal the devastation of her honor to Don Luis (how could she?), but Don Juan (with his story on his return from the war) and the circumstances (in the final encounter of all the characters in the dénouement, see below) do reveal this devastation to Don Luis.

25. Vitse, 2015, p. 40.

26. Cf. Vitse, 2015, p. 40.

27. Soufas, 1988, pp. 167, 172

HIPOGRIFO, Volumen extraordinario, 1, 2018 (pp. 9-21) 


\begin{tabular}{|c|c|}
\hline DON JUAN & $\begin{array}{l}\text { Vuestra cordura, señora, } \\
\text { vuestro gran entendimiento, } \\
\text { el mayor consuelo hallaron } \\
\text { en callar y yo os lo ofrezco, } \\
\text { porque no puedo ofrecer } \\
\text { más; que claro es que no tengo } \\
\text { de casarme porque pude } \\
\text { hallaros en mi aposento } \\
\text { una noche, habiendo sido } \\
\text { quizá causa del suceso } \\
\text { que a dejar os obligó } \\
\text { vuestra casa... }\end{array}$ \\
\hline LEONOR & $\begin{array}{l}\text { Deteneos, } \\
\text { no digáis más, que en pensarlo } \\
\text { miente vuestro pensamiento, } \\
\text { que el honor que me debéis, } \\
\text { tan terso y claro... (p. 1035) }\end{array}$ \\
\hline
\end{tabular}

So, just then Don Diego (Leonor's brother) and Don Luis (her ex-betrothed) enter the scene, and apart from hearing the lady's final words referring to the honor that man owes her, they see her arguing with a cloaked man. Within the framework of the theatrical and social conventions of the Golden Age, it is then impossible to keep the secret of her dishonor. Why is Leonor pleading for her honor from an unknown man? What can the two who have just arrived think?

Second moment: Don Juan unmasks himself to Don Luis (a friend of his) and demands his assistance, as he had placed his confidence in him, reminding him that he had informed him of an incident. Don Luis must respond to this confidence:

DON JUAN $\quad$ Don Luis, mirad que soy yo
con quien reñís; y si vuestro
valor, por venir con él,
os obliga a que a don Diego
(que a mí me debe la vida,
si de otra ocasión me acuerdo)
valgáis, primero acreedor
soy yo de vuestros esfuerzos,
pues de algún suceso mío
parte os he dado primero;
y quien le fio de vos
entonces ya os hizo empeño
de que le valgáis agora. (pp. 1035-1036)

What incident is Don Juan referring to? What tale did he tell Don Luis as proof of friendly and cynical confidence? He means the story of the rape which Don Juan had told to Don Luis as they returned from Fuenterrabía, without identifying the lady: 


\begin{tabular}{|c|c|}
\hline DON JUAN & $\begin{array}{l}\text { Yo quise bien ocho días } \\
\text { y sané luego al momento, } \\
\text { porque aun antes que supiera } \\
\text { casa, nombre, ni quién era } \\
\text { la tal dama, en mi aposento } \\
\text { la hallé una noche dormida, } \\
\text { sin saber quién la llevase } \\
\text { allí, ni qué la obligase } \\
\text { a ser tan agradecida, } \\
\text { donde entregando al olvido } \\
\text { de mi memoria el cuidado, } \\
\text { yendo muy enamorado } \\
\text { salí muy arrepentido. }\end{array}$ \\
\hline DON LUIS & $\begin{array}{l}\text { Pues ¿cómo, sin saber que } \\
\text { vos la amabais, os buscó } \\
\text { esa dama? }\end{array}$ \\
\hline DON JUAN & ¡Qué sé yo! \\
\hline DON LUIS & ¿Quién la trajo? \\
\hline DON JUAN & $\begin{array}{l}\text { ¡Yo qué sé! } \\
\text { Ni de saberlo he cuidado. } \\
\text { [...] } \\
\text { En mi cuarto luz había, } \\
\text { y apenas volví a mirar } \\
\text { quién estaba allí, cuando a ella } \\
\text { la vi en mi cuarto dormir. } \\
\text { [...] }\end{array}$ \\
\hline DON LUIS & $\begin{array}{l}\text { ¿Cómo en tan raro suceso } \\
\text { no preguntastis quién fuese, } \\
\text { ni quién allí la trujese? }\end{array}$ \\
\hline DON JUAN & $\begin{array}{l}\text { ¿Quién me metía a mí en eso? } \\
\text { Si ella se quería ocultar, } \\
\text { ¿preguntarla no sería } \\
\text { quién era descortesía? }\end{array}$ \\
\hline DON LUIS & Pues ¿qué hicistes? \\
\hline DON JUAN & maté la luz. Sin hablar, \\
\hline DON LUIS & ¿Para qué? \\
\hline DON JUAN & $\begin{array}{l}\text { Para que ella no supiera } \\
\text { tampoco allí quién yo era. }\end{array}$ \\
\hline DON LUIS & Pues ¿por qué, don Juan? \\
\hline DON JUAN & $\begin{array}{l}\text { no se pudiera alabar } \\
\text { jamás de que me gozó, } \\
\text { que también tengo honor yo }\end{array}$ \\
\hline
\end{tabular}


y soy mozo por casar

Fuera de que el principal

intento fue que esto hiciese

que mi padre no supiese

que yo había vuelto, pues tal

prevención me aseguraba

de la queja que podía

tener la libertad mía

si allí por su orden estaba,

pues ahora podré negar

en todo tiempo que fui

el hombre que entró hasta allí.

DON LUIS Eso no quiero apurar,

sino saber si después

supisteis quién era.

DON JUAN

¿Yo?

DON LUIS

¿Ni quién la llevó allí?

DON JUAN

No.

DON LUIS

¿Y agora no os mueve, pues,

la curiosidad siquiera

de saber quién es, y allí

la tuvo?

DON JUAN

En mi vida fui

curioso, y antes quisiera

no preguntarlo jamás,

ni que nadie me llegara

a decirlo; que estimara

el no saber della más,

porque estoy ya muy cansado

de saber cómo se llama

y dónde vive mi dama,

qué porte tiene y qué estado,

y así, solo me desvela

pensar que lo he de saber,

porque me muero por ser

caballero de novela

y que se cuente de mi

que una infanta me adoró

encantada, de quien yo

no supe más.

$[\ldots]$

DON LUIS $\quad$ Y ella, ¿qué porte tenía?

DON JUAN Tal, que si algo en este estado me hubiera de dar cuidado,

su ofendido honor sería.

DON LUIS $\quad$ Y en fin, ¿en qué paró? 
DON JUAN En que

antes que me conociera volví a cerrar por de fuera y en el cuarto la dejé. (pp. 1018-1019)

Thus, when Don Juan reminds Don Luis about this story in the circumstances of the dénouement, the lady is immediately identified and Don Luis learns that it was Leonor who was raped («iDon Juan es el que me ha muerto!»). This is no longer a secret for Don Luis y Leonor has not managed to keep it hidden. Don Diego, in turn, does not know all the details, but, on seeing the confrontation between his sister and Don Juan, he demands an explanation of the words «que es puro y terso / el honor que la debéis» (p. 1036): there is little doubt that what is being disclosed here is an affair of honor: it would be difficult to keep the scandal a secret in these conditions.

Third relevant sequence of the dénouement: the arrival of old Don Pedro. His first impulse is to defend Don Juan, but then Leonor begins to speak (for the first time: she can no longer keep the secret even if she says nothing, because it has become common knowledge) and demands that Don Pedro give her the protection he had offered her at the start of the play when he welcomed her into his house because of the fire. As soon as she begins her petition, Don Pedro understands that it is a matter of honor in which he must keep his word, even though it means going against his own son:

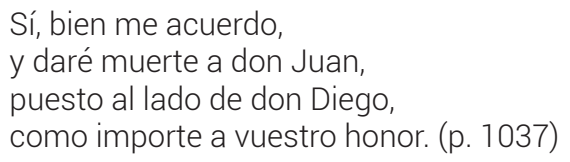

Now Don Juan can only avoid marriage by confronting them all, including his own father. This is too much. Firstly he refuses to attend to Leonor's demands; secondly, he finds himself face-to-face with gentleman with whom he has complicated relationships ${ }^{28}$, to whom he would have to give difficult explanations. In the third and definitive sequence, Don Juan learns from the information given that his own father has given his word to protect the lady who was the object of his rape: in other words, not honoring the lady would mean breaking his father's promise, not acknowledging the authority of old Don Pedro, showing him up and so bringing about his own father's dishonor (and consequently his own). In circumstances like these Don Juan does not have much choice and gives in -but not because of Leonor's strategies.

In any case, what is of interest to me now is not what Don Juan does but rather that Leonor does not by any means manage to keep her dishonor secret. That is to say: even though Leonora has kept quiet about her dishonor, it has become common knowledge. 
Don Luis knows it explicitly. Don Diego states that he has not grasped the secret (p. 1037), a very relative statement: he does not know the details but he does know that his sister has been dishonored. Don Pedro considers that he has fulfilled his obligation by obtaining a promise of matrimony from Don Juan, a fact that can only be understood within the framework of righting a dishonor.

True that this dishonor is only known within a small circle and that it is to be rectified by marriage: but the bride and groom do not love each other; Don Luis is exasperated, as are Don Diego and Marcela. It is all a disaster, and all caused by «chivalrous» Don Juan and his brutal assault. The concluding marriage does not mean happiness either in law or in honor: it is merely damage control, a cover-up, continued silence ${ }^{29}$, which is what is best, because in affairs of honor (really affairs of dishonor) «no hay cosa como callar».

\section{BIBLIOGRAPHY}

Antonucci, Fausta, «Riflessioni su No hay cosa como callar e sulla sua appartenenza di genere», en Giornate Calderoniane Calderón 2000: atti del Convegno Internazionale, ed. Enrica Cancelliere, Palermo, Flaccovio, 2003, pp. 159-169.

Arellano, Ignacio, «No hay cosa como callar de Calderón: honor, secreto y género», Rilce, 29, 3, 2013, pp. 617-638. Available online: <https://www.unav.edu/publicaciones/revistas/index.php/rilce/article/view/2867/2700> [29/10/2017].

Arellano, Ignacio, «Calderón y los géneros dramáticos con otras cuestiones anejas: honor, amor, legitimación política y autoridad de las taxonomías», Rilce, 34, 1 , 2018, pp. 100-126.

Calderón de la Barca, Pedro, Obras completas. I. Comedias, ed. Ángel Valbuena Briones, Madrid, Aguilar, 1987.

Déodat-Kessedjian, Marie Françoise, El silencio en el teatro de Calderón de la Barca, Pamplona/Madrid/Frankfurt, Universidad de Navarra/Iberoamericana/ Vervuert, 1999.

Escudero, Juan Manuel, «Dislocaciones genéricas calderonianas. El llamativo caso de No hay cosa como callar», Anuario Calderoniano, 6, 2013, pp. 75-93.

Mata, Carlos, «"Llorar los ojos y callar los labios": la retórica del silencio en No hay cosa como callar», Anuario calderoniano, 3, 2010, pp. 259-274.

Rodríguez Cuadros, Evangelina, «Antes que todo es la acción: para una lectura de No hay cosa como callar de Calderón», Cuadernos de Teatro Clásico, 1, 1988, pp. 27-50.

29. Why do they not demand more detailed explanations about such a sudden wedding? Because it is evident to all that this is an affair of honor, a taboo subject, which must be mentioned as little as possible. They do not talk or comment, not because they do not know the secret, but rather because they do know it, because only the knowledge that dishonor has occurred can force them all into silence. Further thoughts on the silence in this play in Mata, 2010. 
Soufas, Teresa S., «"Happy Ending" as Irresolution in Calderón's No hay cosa como callar», Forum for Modern Language Studies, 24, 2, 1988, pp. 163-174.

Vitse, Marc, «No hay cosa como callar, pieza límite», en Calderón frente a los géneros dramáticos, ed. Antonio Sánchez Jiménez, Madrid, Ediciones del Orto, 2015, pp. 27-43. 
